JURNAL KEILMUAN DAN TERAPAN TEKNIK MESIN

DINAMIKA TEKNIK MESIN

ISSN 2088-088X
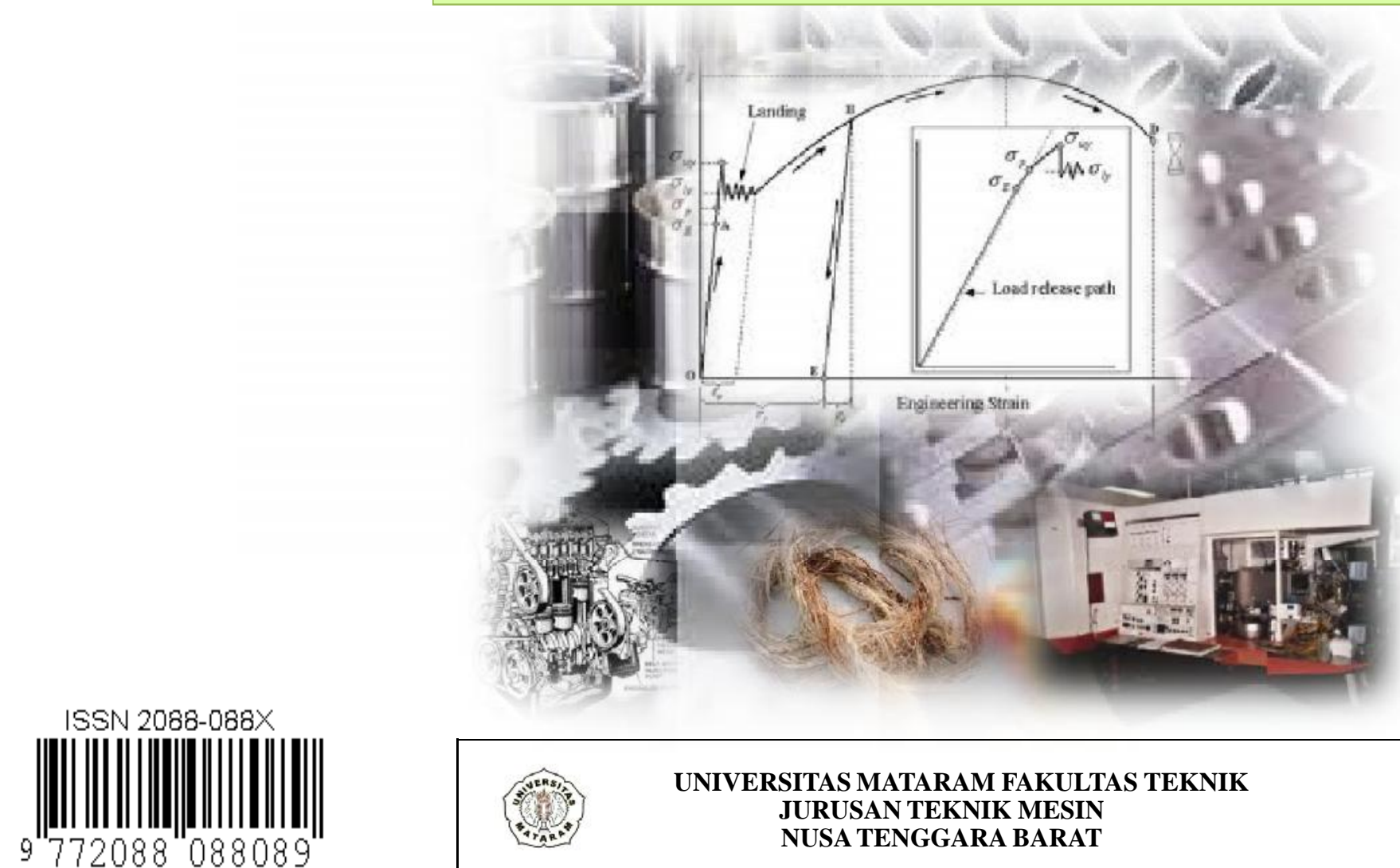

JURUSAN TEKNIK MESIN 


\section{PEDOMAN SINGKAT BAGI PENULIS}

Vol. 1 No. 2 Juli 2011

\section{JURNAL KEILMUAN DAN TERAPAN TEKNIK MESIN}

Diterbitkan oleh Jurusan Teknik Mesin Fakultas Teknik Universitas Mataram dengan frekuensi terbit dua kali setahun setiap bulan Januari dan Juli

Alamat Redaksi: Jurusan Teknik Mesin Fakultas Teknik Universitas Mataram

JI. Majapahit No. 62 Mataram Nusa Tenggara Barat Kode Pos: 83125

Telp. (0370) 636087; 636126; ext 128 Fax (0370)636087

Email : Dinamikamesin@ftunram.net; Made.Mara@ymail.com

\begin{tabular}{|ll|}
\hline & DEWAN PENYUNTING \\
Penanggung Jawab & : Sinarep, ST. MT \\
Pemimpin Umum & : I Made Mara, ST. M.Sc \\
Ketua Penyunting & : Paryanto Dwi Setyawan, ST. MT \\
Bendahara & : Nasmi Herlina Sari, ST. MT \\
Penyunting Ahli & : Syahrul, ST. M.A.Sc. Ph.D \\
& Yuli Panca Asmara, ST. M.Sc. Ph.D \\
& I Made Miasa, ST. M.Sc. Ph.D \\
Penyunting Pelaksana & : I Made Nuarsa, ST. MT \\
& Nurpatria, ST. M.Eng \\
Tata Usaha dan Sirkulasi & : Ahmad Iryanto, ST \\
\hline
\end{tabular}

Dinamika Teknik Mesin adalah jurnal ilmiah sebagai forum komunikasi dalam kajian teori dan aplilkasi Teknik Mesin yang meliputi bidang Mekanika dan Bahan, Produksi dan Energi. Artikel yang dipertimbangkan untuk dimuat adalah berupa hasil penelitian yang belum pernah diterbitkan atau tidak sedang menunggu diterbitkan pada publikasi lain.

Untuk makalah yang diterbitkan dalam jurnal Dinamika Teknik Mesin akan dikenakan biaya sebesar Rp. 200.000,00. Biaya ini dapat ditransfer ke Bank BCA Cab. Mataram dengan no rek. 0560809611 a.n: Nasm Herlina Sari, ST dan bukti transfer pembayaran harap dikirim atau difax ke alamat redaksi.
Petunjuk umum

Redaksi menerima tulisan/naskah/karya ilmiah yang meliputi hasil pemikiran dan hasil penelitian dalam bidang teknik mesin yang terbuka untuk umum Tulisan harus asli, bukan merupakan terjemahan atau saduran dari artikel lain.

\section{Penulisan Naskah}

Naskah ditulis dalam Bahasa Indonesia atau Bahas Inggris. Naskah diketik satu spasi dengan MS-Word, huruf Arial 10 pada halaman kertas A4 dalam dua kolom kecuali abstrak. Jumlah halaman maksimal 15 halaman kemudian direkaman dalam CD. serta dicetak pada kerlas A4 lanpa kolom dengan huru arial 12 dengan spasi 2 sebanyak dua eksemplar

\section{Halaman judul}

Judul tulisan singkat dan padat, tidak menimbulkan penatsiran beraneka ragam. Untuk judul dalar Bahasa Indonesia ditulis selunuhnya dengan huru capital secara simetris (1 spasi, Arial 12, bold).

\section{Sistematika penulisan}

Artikel hasil penelitian adalah : Judul; nama penulis (tanpa gelar akademik); abstrak (maksimum 200 kat dalam bahasa Indonesia (jika tulisan dalam bahasa inggris) Bahasa Inggiris (jika tulisan dalam bahasa Indonesia) dicetak miring dengan spasi satu dan huru arial 10); dengan 3-5 kata kunci; pendahuluan (tanpa sub judul) yang berisi I atar belakang dan tujuan atau ruang lingkup tulisan; tinjauan pustaka: metode penelitian; hasil dan pembahasan; kesimpula dan saran; daftar pustaka (hanya memuat sumbersumber yang dirujuk).

Nama Penulis

Ditulis di bawah judul tanpa gelar, dengan hurut Arial 10 dan judul

2. Apabila penulis lebih dari satu orang, semua penulis dicantumkan secara

3. Nama institusi dan alama korgandensi ditulis di bawah nama penulis.

\section{Teknik Penulisan}

1. Untuk kata asing dipergunakan huruf miring.

Alinea baru dimulai pada 1,27 cm (1 ketukan ab) dari batas tepi kiri. Antar alinea tidak diber tambahan spasi.

Semua bilangan ditulis dengan angka, kecual pada awal kalimat.

Naskah diketik di kertas A4 dalam dua kolom, lebar masing-masing kolom $7,25 \mathrm{~cm}$

5. Tabel hanya diberi garis horizontal yang sederhana, tidak perlu garis vertikal atau varias bentuk yang macam-macam, seperti dishadow, (jika terpaksa) dapat dibuat satu kolom.

(jika terpaksa) dapat dibuat satu kolom.
$3,5 \mathrm{~cm}$, kanan $2,5 \mathrm{~cm}$. Header $1,27 \mathrm{~cm}$ dan Footer 1,27. Nomor halaman digunakan huru' arial 8.

7. Tabel dan gambar harus diberi judul nomor yang diurutkan dari $1 \mathrm{dst}$, dan ditempatkan ditengah. Judul tabel ditempatkan pada bagian atas, sementara judul gambar ditempatkan pada bagian bawah. Bila tabel atau gambar merujuk pada suatu sumber, maka sumber harus dituliskan pada bagian bawah.

8. Sumber pustaka dituliskan dalam uraian harus disertai nama penulis, tahun penerbitan dan nomor halaman tempat asal kutipan Contoh: menurut Herman.... (2000: 15), dst bila ditempatkan di awal paragraf. Bila ditempatkan pada bagian akhir paragraf ditulis seperi pada. (Anggodo, 2000:40).

9. Daftar pustaka ditulis dalam urutan abjad nama penulis secara kronologis.

a. Untuk buku; nama pokok dan inisia pengarang, tahun terbit, judul, jilid, edisi, nama penerbit, tempa terbit.

b. Untuk tulisan dalam buku; nama pokok dan inisial pengarang tahun, judul karangan, inisial dan nama editor, judul buku, nomor halaman permulaan dan akhir dari karangan tersebut, nama penerbit dan tempat terbit.

c. Untuk tulisan dalam jurnal/majalah; nama pokok dan inisial pengarang tahun, judul karangan, singkatan nama majalah, jilid (nomor), nomor permulaan dan akhir karangan.

10. Penulisan rumus/formula/model matematika dimulai pada 1,27 cm (1 ketukan tab) dari atas tepi kiri, diberi nomor urut (1), (2) ds.

11. Lampiran diberi nomor urut A, B, dst dan ditempatkan langsung di bawah Daftar Pustaka.

12. Panjang tulisan beserta lampiran maksimum 10 halaman. 